$\tau_{0}>2 \cdot 10^{-9}$ sec., in agreement with the results of other observers ${ }^{4}$. The high value of the mean energy $\left(\sim 10^{10} \mathrm{eV}.\right)$ of $\mu$-mesons at this altitude indicates that the average energy of production of the $\mu$-mesons, or of the $\pi$-mesons of which they are the decay products, is large compared with the value $\bar{E}$ given above. This is consistent with the assumption that the $\mu$-mesons result from the much more energetic disintegration stars produced in the high atmosphere.

${ }^{2}$ Rochester, G. D., Rev. Mod. Phys., 21, 20 (1949). Jánossy, L., and Rochester, G. D., Proc. Roy. Soc., A, 183, 181 (1944).

Occhialini, G. P. S., and Powell, C. F., Nature, 162, 168 (1948).

- Burfening, J., et al., Phys. Rev., 75, 382 (1949).

- Camerini, Muirhead, Powell and Ritson, Nature, 162, 433 (1948).

'Harding, J. B., Lattimore, S., Li, T., and Perkins, D. H., Nature, $168,319(1949)$.

- Harding, J. B., Nature, 163, 440 (1949).<smiles>[111InH]</smiles>

\section{ANNUAL REPORT OF THE FORESTRY COMMISSIONERS}

$\mathrm{T}$

HE report of the Forestry Commissioners for the year ending September 30, 1947 (London : H.M. Stationery ONP ; 1948), covers the first complete year of thpepost-war forestry programme. Forest policy canye under review in the House of Commons in Nopnfoer 1945 and again in October 1946. On thip latter occasion the Minister of Agriculture and Fis Feries made an important announcement which mas, in fact, a full statement on forestry.

The opening portion of this statement merits careful study, and runs as follows: "On 30th November last year I made a statement in this House on Government Forest Policy. After careful and detailed study, the Government were impressed with the necessity, as a safety measure, apart from all other considerations, to rebuild our reserves of standing timber as quickly as possible. The Government were also impressed with the possibilities that systematic forestry and afforestation held out for the better utilisation of large areas of poor land, and increased employment in healthy rural surroundings for quite a considerable body of people. We proposed, therefore, at that time to ask the Forestry Commission to prepare for what we regarded as largescale action. My right hon. Friend the Chancellor of the Exchequer readily agreed to replenish the Forestry Fund by some $£ 20$ million during the five years 1946-50. The first instalment of that figure appears in the Estimates for the current financial year. This sum of $£ 20$ million is expected to provide for the afrorestation and replanting of something like 365,000 acres by State action and by assistance to owners of private woodlands, for the acquisition of land, for increased facilities for education, training and research into all branches of forestry, for up-todate houses for forestry workers, and for national forest parks; , and in addition, of course, the maintenance and development of the large areas of young plantations already established by the Forestry Commission."

It is common knowledge that the First World War considerably depleted the woodlands of Britain --practically all privately owned and grown woodlands. 'I'he Second World War has nearly cleared all the conifer areas, and the hardwood areas since the close of the War are now bearing the brunt of home fellings to a dangerous extent. It was the tardy recognition by the Government in 1919 of our almost total dependence on imports of the soft-wood timbers which caused the Forestry Bill to be passed in the House of Commons.

We are in whole agreement with the Minister in his belief that timber will remain an essential raw material for industry for a long time. But his reason for speeding up planting operations in Great Britain --because in the great forests from which the over. seas supplies had come the growth was not keeping pace with the depletion-is a sorry statement for a Minister of State to make on the forest administration of the Colonial Empire (it would not be true of India, but she is no longer in question). It is true the forests have been regarded mainly from the point of view of luxury timber producers, worked to this end by timber merchants, the Government taking absurdly small royalties for a produce which belonged to the people of the country it was ruling.

The report also deals with the dedication scheme for the owner of private woodlands. But since the report was written it would appear that some modifications will be necessary in the Commission's original ideas on this subject.

The following programmes are of interest for the five-year period 1946/47-1950/51. The planting programme is : England, 118,400 acres; Scotland, 123,400 ; Wales, 48,200; private forestry, 75,000. Total, 365,000 acres. The land acquisition programme is: England, 420,000 acres; Scotland, 330,000 ; Wales, 176,000. Total, 926,000 acres-or nearly a million acres in the five years.

The Commission may be congratulated on having produced a concrete plan which can be worked to without the ambiguities which are overshadowing so much of the piecemeal, so-called town-planning and other operations throughout Great Britain. Some of these latter are in the hands of more than one controlling or advisory authority; and the conflicting interests thus engendered appear, in some cases, to be dangerously imperilling the future food-raising possibilities by taking fertile agricultural land for building or new road work and so forth.

\section{NEW SOUTH WALES UNIVERSITY OF TECHNOLOGY NEW APPOINTMENTS}

TN connexion with the founding of the New South 1 Wales Unjersity of Technology (see Nature, July 30 , p. 195) appointments in the University have been made as follows.

Chair of Electrical Engineering: $M r . H . J$. Brown. For the past two years Mr. Brown has been acting assjotant director of the University of Technology and co-ordinator of research in the Technical Education Department. He will be responsible for the co-ordination of research in the new University. He graduated at Sydney, and has worked in the research labora. tories of Amalgamated Wireless and as an electrical engineer in the Tasmanian Hydro-Electric Commission. During the War he became principal research officer in the Council for Scientific and Industrial Research and was one of the leaders in radar research and development.

Chair of Architecture: $M r . F . E$. Towndrow. Mr. Towndrow is at present head of the Department of 